\title{
Eşikten Mekâna-Mekândan Yere Yeldeğirmeni-Rasimpaşa Mahallesi
}

\author{
K. Pınar Kırkık Aydemir ${ }^{*}$, Mekselina Gececi ${ }^{2}$ \\ 1* Bolu Abant İzzet Baysal Üniversitesi, Mimarlık Fakültesi, Şehir Bölge Planlama Bölümü, Bolu, Türkiye, (ORCID: 0000-0002-1331-1655), \\ mimar844@gmail.com \\ 2 Biruni Üniversitesi, Mühendislik ve Doğa Bilimleri Fakültesi, İç Mimarlık ve Çevre Tasarımı Bölümü, İstanbul, Türkiye (ORCID: 0000-0001-9296-3813), \\ mgececi@biruni.edu.tr
}

(International Conference on Design, Research and Development (RDCONF) 2021 - 15-18 December 2021)

(DOI: $10.31590 /$ ejosat.1045528)

ATIF/REFERENCE: Kırkık Aydemir, K. P., Gececi, M. (2021), Eşikten Mekâna-Mekândan Yere Yeldeğirmeni-Rasimpaşa Mahallesi. Avrupa Bilim ve Teknoloji Dergisi, (32), 275-281.

\section{$\ddot{O} \mathbf{z}$}

Kent ve mimari birbirini etkileyen, dönüştüren iki ana mekânsal unsurdur. Kentsel yerleşim; yapı adalarının boyutları, sokak örüntüleri vb. kentsel peyzaj diziminden oluşurken; mimari yapıların yatay ve dikey bileşenleri, bina yüksekliği, çekme mesafeleri, cephe genişliği, pencereler, kapılar vb. özelliklerden şekillenmektedir. Bu noktada mimari eşikler, gün içerisinde sıkça gelip geçtiğimiz geçiş mekânları oluşturmanın yanı sıra, bir yapı arakesiti olarak mimariyi zenginleştiren detaylardır.

Günümüz kentlerinde görülen tek tip yapılaşma çevreden kopuk mimari tasarımlar ile kentin tarihsel ve kültürel değerlerini yansıtmaktan oldukça uzak kalmakta ve algısal açıdan yaşanılan mekân ile kişisel bağ kurulmasını güçleştirmektedir. Bu durum kentsel hafızanın her geçen gün zarar görmesine sebep olmakta ve İstanbul'da yaşayanları kente yabancılaştırmaktadır.

Bu çalışmada, mekân-yer diyalektiği eşik öğeler üzerinden "yer olabilme” şeklinde ele alınmıştır. Yeldeğirmeni-Rasimpaşa Mahallesi'nde bulunan ve günümüzde unutulmaya yüz tutan cumbalı, çıkmalı, arkadlı, saçaklı, ahşap çatkılı duvar gibi mimari biçimler “eşik oluşturan ögeler” olarak incelenmektedir. Yeldeğirmeni- Rasimpaşa Mahallesinde eşik ögeler; kapı-pencere, duvar, merdiven, kaldırım, peyzaj donatıları, cumba-çıkma, saçak, arkad, sütun-kolon vb. yapısal öğeler; avlu (atrium,) ve pasaj alanları; kaldırım kafeler ve yeme-içme yerleri olmak üzere 3 sınıfta ele alınmıştır. Alan çalışması ile elde edilen bulgular Kadıköy Belediyesi’nden temin edilen 1/1000 Uygulama İmar Planı ve 1/15000 ölçekli Nazım İmar Planları üzerine işlenmiştir. Alan çalışması ve literatür araştırmasına dayalı olan çalışmada Yeldeğirmeni Rasimpaşa Mahallesi'nin İstanbul'da taşıdığı eşik öğeler açısından zengin bir semt olduğu, İstanbul'da yerel bir ara kesit oluşturarak, "yer" algısına örnek bir mekânsal dizim sergilediği sonucuna varılmıştır.

Anahtar Kelimeler: Eşik, yapı, mekân, yer, yer algısı, Yeldeğirmeni-Rasimpaşa Mahallesi.

\section{From Threshold to Space-From Space to Place Yeldegirmeni- Rasimpasa Neighbourhood}

\begin{abstract}
Urban and architecture are two main spatial elements that affect and transform each other. While urban settlement consists of urban landscape like dimensions of building blocks, street patterns, the architectural form includes the horizontal and vertical components of the buildings, the height of the building, the width of the facade, the windows, the doors, the building indentations and protrusions, etc. formed by features. At this point, architectural thresholds are a building intersection, as well as creating transition spaces that we come and go through frequently during the day; facade elements, building entrances are the details that enrich the architecture.

The uniform construction seen in today's cities is far from reflecting the historical and cultural values of the city with abstract architectural designs from the environment and makes it difficult to establish a personal connection with the place. This situation causes
\end{abstract}

*Sorumlu Yazar: kiymetpinar.aydemir@ibu.edu.tr 
urban memory to be damaged day by day and alienates those living in Istanbul from the city. Thresholds; as the building entrance and the details of the entrance, it stands out as the details that bring awareness to the city and architecture, increasing the perception of place.

In this study, the space-place dialectic is handled as "being a place" through threshold elements. Traditional architectural details such as a bay window, overhanging, arcaded, fringed, wooden framed wall in Yeldeğirmeni-Rasimpaşa District, which are now being forgotten, are examined as "threshold-forming elements". Threshold elements in Yeldeğirmeni- Rasimpaşa Neighborhood; entrance and physical recesses and protrusions and details of the entrance (door-window, wall, stairs, pavement, landscaping equipment, bay window, eaves, arcade, column-column, etc.), courtyard (Atrium), passage areas, building interfaces (pavement cafes and eating and drinking places) are discussed in 3 sections. The findings obtained from the fieldwork were processed on the 1/1000 Implementation Development Plan and 1/15000 scale Master Development Plans obtained from Kadiköy Municipality. In the study, which is based on fieldwork and literature research, it is concluded that Yeldeğirmeni Rasimpaşa neighborhood is a district rich in threshold elements in the metropolitan city of Istanbul, and that it exhibits an exemplary spatial syntax for the perception of "place" by forming a local cross-section in the metropolitan city Istanbul.

Keywords: Threshold, building, space, sence of place, Yeldeğirmeni-Rasimpasa Neighbourhood.

\section{Giriş}

Mekân, "irili ufaklı, doğal ve yapay boşluklarda oluşan, insanların içinde yaşadığı yaşamsal çevreler"dir (Ayyıldız, 2000, s.22). Kamusal mekân ise toplumsal iletişimin gerçekleştiği, fiziksel olarak herkesin erişebildiği, geçirgen ve devingen alandır (Taşc1, 2014, 4-10). Mekân kavramı fiziksel olduğu kadar psikolojiktir. Çevresel psikolojide mekân, bireylerin psikolojik deneyimlerinin ve sosyal aktivitelerinin gerçekleştiği, inşa edilmiş fiziksel çevre olarak tanımlanmaktadır (Ujang, 2009, s.156). Sadece fiziksel koşullarıyla algılanmaması gereken mekân; anlam, farkındalık, aidiyet, kimlik ve yaşam kültürünün taşıyıcısıdır (Şentürk, 2018, s.11). Bu sebeple kentsel mekânı bir tasarım nesnesi olarak değil, toplum-mekânı içinde barındıran bir "yer"; tarihsel, ekonomik, politik, toplumsal, zihinsel, algisal, deneyimsel, görsel vb. birçok katmanlar şeklinde incelemek gerekmektedir. Tarih boyunca mimari çevrenin, insan ihtiyaçlarına ve davranışlarına uygun hale gelmesi için birçok değişim geçirdiği bilinmektedir. Özellikle modernleşme sürecinde artan tek tip yapılaşma yaklaşımı; tarihsel sürekliliği ve süslemeyi yadsımış, yöre ve gelenekleri yok sayarak, bağlam, kültürel kimlik ve geçmişten kopuk bir yaşam tarzı dayatmıştır (Aytıs, 2010). Süreç içerisinde kentsel ölçekte mevcut yapısal dokunun korunması ya da tahrip olmasına sessiz kalınması, çağdaş eklerin bu doku ile ilişki kurarak kentsel mekâna katılması ya da "ayrık" durması gibi çelişkiler ile mekânı sorgulama gereği doğmuştur. Bina ve yapıların farkındalık oluşturan fiziksel formları olan "eşikler" göz ardı edilmiş, yerin bağlamından uzak yapılaşmanın artmasıyla kentsel nüfus uydu kentler ve kapalı sitelere yerleştirilmiştir. Mimari çevre sosyal ve psikolojik ihtiyaçlara da imkân tanımalıdır. Yapıların birey davranış üzerinde etkisine yoğunlaşan birçok çalışma vardır (Ittelson,1960; Cassidy, 1997; Lynch, 1960; Gibson, 1979). Milgram (1972) kentsel mekânı cadde, bina ve diğer yapılar ile ilişkilendirerek kentsel mekânda "yer olabilme" potansiyelini sorgulamakatdır.

Yatay ve düşey sınırlar oluşturarak iç-dış, özel-kamusal arasında biçimlenen geçiş alanları, yapı doluluk ve boşlukların üst üste bindirilmesiyle oluşan arayüzler gündelik hayatta karşımıza sıklıkla çıkmaktadır (Gezer, 2014 s. 227-258). Bu arayüzler bilinçsiz olarak kente katılarak yapıdan ayrı olduğu düşünülen eşik mekânları oluşturmaktadır. Bu çalışmada eşik mekânlara içdış ortam arasındaki belirsiz, tanımsız alanlar olarak değil, istenilen düzeyde çevre ile bütünleşen kontrollü kentsel boşluklar olarak bakılarak, Yeldeğirmeni-Rasimpaşa Mahallesi'nde tespit edilen eşik mekânlarının, kent kimliğinin yeniden kurgulanmasında ve kent yurttaşlarında "yere aidiyet" hissinin yeniden oluşturmasında barındırdığı imkanlar ele alınmıştır.

\subsection{Kentsel Mekânda "Yer olabilme" ve "Eşik"}

Montgomery (1998)'e göre “yer” fiziksel şekil, aktivite ve anlam tarafindan inşa edilir. Bir yer üzerinde değerlendirme yapmanın herhangi bir şekli, yeterli fiziksel ve sosyal bileşenler olmadan yapılamaz. Dolayısıyla yer ilişkisi bireyler, insan, davranış, eylem, inanış, buluş, duygular ve etkilerin iç oyunu ile ifade edildiği özel yerler arasındaki bağ ya da etkili bağların gelişimi olarak da belirtilebilir (Hidalgo ve Hermandes; 2001, s.274). "Yer olabilme" belli bir mekân ve birey arasındaki güçlü ilişki ağının bir sonucudur. Fiziksel çevre kullanıcılarının yeri tanımlayabilmesinde ve yeri sahiplenmesinde, yeri okunabilir görmesi oldukça önemlidir. Lynch (1981) çalışmasında yeri okunaklı yapan özelliklerin landmarklar, dügüm noktaları, bölgeler, sınırlar, yollar olduğunu vurgulamaktadır. Dolayısıyla bir yerin estetik, canlı, hareketli, sade, doğal, kullanışlı vb. duygular ile nitelendirilebilmesi yerin görüntüsü, kullanımı, işlevi vb. çevresel koşullar ile yakından ilişkilidir (Jacops, 1961; Montgomery, 1988).

İnsanların yaşadıkları yere bağlılık hissetmesi, o yerin kimlik oluşumuna katkı sağlamaktadır (Ujang, 2009, s.156). Günümüz kent yapısında, yer kavramı nesneleştirilmiş ve yerel kimliğin kaybolmasına sebep olarak kent kimliğini zayıflatmıştır. Kimliğin kaybolması; deneyimlediğimiz mekânın anlamını, çeşitliliğini yitirmesi ve mekâna olan bağlılık hissinin azalması demektir (Ujang, 2009, 156-157). Arefi'ye göre modernite mekânın nesneleşmesi ve değersizleşmesi yolunu açmıştır (Arefi, 1999, s.179-180). Son y1llarda kentte yaşayanlar arasında büyüyen tedirginlik duygusu; yersizliğin, özgün olmamanın, tek tip kent yapısının bir sonucudur (Arefi, 1999, s.184). Le Corbusier, "Evimizden çıkmak demek köşeyi döner dönmez geçen arabalar tarafından öldürülme tehlikesiyle karşı karşıya olmak demektir." sözleriyle modern kentlerin onun üzerindeki etkisini tarif etmiştir (Berman, 2018, s. 224). Chicago Okulu ve öncüleri de kentleri yabancılaşmış olarak tanımlamaktadır. Sosyolog Louis Wirth'e göre yerle olan toplumsal bağların zayıflaması, gayri resmi toplumsal kontrolün çökmesiyle kentleri yabancılaşmaya sürüklemektedir (Geiss, 1998, s.232).

Dematteis (1994) yer kimliğini kent üzerinden açıklamaktadır; "Bir kentin kimliği, kendisini tanımlayan kentsel müşterekliği ifade eder. Başka bir deyişle; biz kent kimliğini, bu müşterekliğe tutarlılık ve süreklilik kazandıran bir olgu ve bireyleri belirli bir fiziksel çevreye bağlayan aktörler ve ilişkiler dizisi olarak görüyoruz. Dolayısıyla; yer kimliği, o yere sahip bir grubun kimliğidir”. Proshansky (1983) ise bireylerin, öz kimlik 
ve yer kimliği olmak üzere iki kimliğe sahip olduğundan bahsederek; yer, yerlilik ve kentli bakış açısı ile bakılması gerektiğini vurgulamaktadır. Kentte yaşayanların kendilerini mekânın bir parçası olarak görmelerini ve mekân üzerinde hak ve sorumluluk hissetmelerini, yer ve yerel kimlik, kent kimliği

ile ilişkilendirilmektedir. Proshansky (1983)' e göre kentin bir parçası olmak, kente ait olmakla ilişkilidir. Aitlik kavramı ise yerin ruhu, yere bağımlılık, yerin kimliği kavramları üzerinden yere bakmakla mümkündür (Şentürk, 2018, s.11).

David Harvey (2011), içinde yaşadığımız dünyayı, bireysel ve kollektif iradeyi karmaşık bir yapı olarak nitelendirmiştir. Harvey, bu yapının içinde insanın alternatif bir yaşam biçimi oluşturmak için mücadele içine girmelerinin nasıl mümkün olabileceğini sorgulamaktadır. Buna göre insanların yaşadıkları kente karş1 aidiyet hissetmeleri için verilmesi gereken mücadelenin neye ve kime karşı yürütülmesi gerektiğinin sorgulanması gerekmektedir. Harvey (2013) "Kapitalizm mütemadi olarak ürettiği artı ürünün soğurulması için şehirleşmeye ihtiyaç duyar" sözüyle bu mücadelenin kapitalizmle ilgili olduğuna işaret etmiştir. Lefebvre (2013) ise şehir ile kent arasında bir ayrım olduğunu vurgular. Ona göre toplum bir bütün halinde kentleşmektedir. Bu kentleşme şehri yıkarak işlemekte, dolayısıyla bir oluş haline işaret etmektedir. Kapitalist kentleşme ile "şehir hakkı" olarak adlandırılan, insanların istekleri doğrultusunda gerçekleşen kentleşme, Marshall Berman (2014) tarafindan mekanik ve diyalektik modernleşme olarak ifade edilmiştir. Mekanik açıklama eski olan her şeyi modernizm karşıtı olarak görür ve sürekli bir yenilik adına insan faktörünü göz ardı etme eğilimi gösterir, yani insana dişsaldır. Lefebvre'nin de Harvey'nin de kentleşme eleştirisi, tam da bu modernizm anlayışının eleştirisidir (Öztürk, 2016, s.264-265).

Modernizm sonrası gelişen post-modernizm dönemi ise yap1 ve mekân tasarımında bağlam, kültürel kimliği tekrardan sorgulayarak, ülkeleri, şehirleri, geçmişten bugüne, günümüzden de geleceğe kendi değerlerini aktarmaları konusunda bir uyanış hareketini başlatmıştır. Toplumun geçmişten günümüze yaşadığ kültür ve değer yargılarını yansıtan mimari-planlamaya olan ihtiyacı net bir şekilde ortaya koymuştur. Hızla değişen kentlerde, yurttaşların aidiyet hissini yitirmemeleri ancak toplumsal ve kültürel değerlerin varlığının yeni oluşan kent dokusu içerisinde sürdürülmesiyle olacaktır. $\mathrm{Bu}$ bağlamda kentsel aidiyetin korunmasına ve yeniden kurgulanmasına imkân veren eşikler, kent içerisinde bir mekansal arayüz olarak var olurlar. Bu arayüzler zaman içerisinde kent gelişiminin ve yenilenmesinin karşısında durmayarak mevcut kent dokusu koruyan yeni tasarımlara olanak sağlamaktadır.

\subsection{Kavramsal Bakış Açısından Mimari Bakış Açısına Bir Arayüz Olarak "Eşik"}

Eşik coğrafi bakış açısı ile arazinin içinde bulunduğu topografik yükselti olarak bilinirken gündelik hayat içerisinde çoğunlukla karşımıza çıkan aşama ya da sınır olarak algılanmaktadır. Peyzaj planlamasında eşik, kentsel ve kırsal alanlarda planlamayı yönlendiren maksimum dayanım, kullanım kapasitesi olarak ele alınmaktadır. Kırsal peyzaj planlamasında, planlamayı yönlendiren en önemli eşik doğal kaynakların kullanım kapasitesi iken kentsel peyzaj planlamasında, ucuz altyapı maliyetleri ile geliştirilebilir alanların tespit edilmesidir (Tuncer, 2012).

Eşik kavramı aşama açısından ele alındığında bir durumdan diğer bir duruma geçerken karşılaşılan engeller, kısıtlamalar e-ISSN: 2148-2683 şeklinde tanımlayabilir. Sınır anlamında eşik; bütünün farklı iki alanını ayırmakta kullanılmaktadır. Farklı bölgesel haklara sahip alanlar arasındaki geçiş ve bağlantıyı sağlamaktadır. Genel olarak eşik çoklu bir aradalık durumu, farklılıkları bir arada tutan etkileşim alanları olarak da nitelendirilmektedir. Kentsel alanda eşik mekânları Foucault'nun heterotopoloji kuramının temel koşullarından da birini teşkil etmektedir. Heterotopik olarak eşik karşıtlıklar arasında geçici karşılaşma koşullarını yaratarak toplumsal biraradalık imkânı sunmaktadır. Bourdieu (1977) eşiği "karşıtların buluşma alanı" olarak yorumlamaktadır. Eşikte olmak kavramı mekânsal olarak "arada olmak" anlamında iki farklı bağlamı içinde barındırmaktadır. Dolayısıyla eşik karşılıklı olarak birleşme ve ayrılma koşullarını bünyesinde taşımakta, özelkamusal alan arasında "geçiş" rolünü üstlenmektedir (Şevik ve Çalışkan, 2018, s.892).

Eşikte kalma durumu "içeri” girme ihtimaline de kapı açar. Dolayısıyla eşik mekândakini ve mekân dışındakini bir araya getirmekte, etkileşim imkânı tanımaktadır. Bu sebepledir ki Shulz (1971) "bir mekânın girişini, etkileşimin temelini oluşturan ve mekâna hayat veren kısım" olarak atfetmiştir. Ovink (2012) eşiğin birçok görevi olduğunu belirterek, eşiklerin şehrin görsel bütünlüğünü koruduğunu vurgulamaktadır (Bertlin, 2014, s.35). Bloomberg vd., (2013)'ne göre de eşik, bina ön cephelerindeki pencere ve açıklıklar, balkonlar, yapı malzemeleri dokusu ve rengi, girinti-çıkıntılar, saçaklar, sundurmalar, gölgelikler, tenteler, brandalar vb. dış cephe elemanları olarak değerlendirilmiş, buna ilave olarak yayalar ve oturanlar için mekâna ritim ve görsel etki katan arayüzler, geçiş mekanları olarak incelenmiştir (Şekil 1).

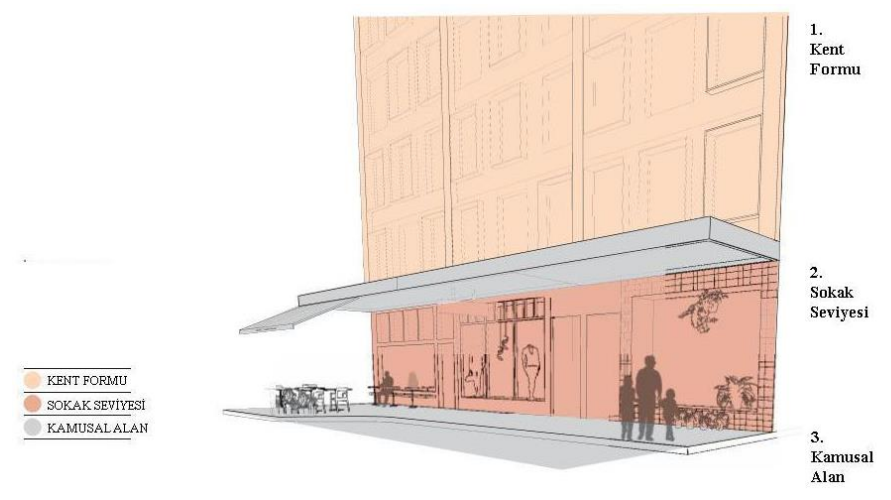

Şekil 1. Eşiğin yapı ve kent formu ile bağlantısı (Adelaide Design Manual, 2014).

Eşik, geçiş alanları tanımlarken hem bir arayüz, hem de iç ve dış arasında bir sınır oluşturmaktadır (Selçuk ve Sorguç, 2016, s.54). Köknar, yatay ve dikey bileşenleri olan arayüzleri, "kent ortamında "serbest kalınan", "gündelik stresten kopulan" ve "buluşulan eşikler" olarak tanımlanmıştır (Gökçen, 2019, s.129137).

\section{Meiss (1986) eşiği;}

1-) Giriş ve girişe ait fiziksel girinti-çıkıntı ve detaylar (kapıpencere, duvar, merdiven, kaldırım, peyzaj donatıları, cumbaçıkma, saçak, arkad, sütun-kolon vb.),

\section{2-) Avlu (Atrium), pasaj alanları}

3-) Yapı arayüzleri olan kaldırım kafeler ve yeme-içme yerleri, olmak üzere farklı açılardan ele almaktadır (Dizman, 2015, s.17-19) 
Mimari açıklıklar olan eşikler; girişte bazı yerlerde, sadece kapı, pencere, duvar, saydam cephe, basamak, kaldırım, cumba, çıkma, saçak, arkad, vb. detaylardan oluşmakta iken, bazı yerlerde aydınlatma ve peyzaj ögeleri ile yönlendirici geçiş alanı olan avlulara dönüşmekte, bazı yerlerde ise ticari birimlere işlev kazandıran veranda, tabela vb. fiziksel ögelerle desteklenen yeme-içme mekânları, perakende, kafe, restoran gibi yapı ile uyumlu, yüksek kullanıcı profili olan köşeler haline gelmektedir.

\subsection{Mekândan Yere "Eşik"}

Mekân bize bazen boşluğun biçimi, ölçeği ve kurgusunu yansıtırken, bazen de yaşamın bu mekânlarda nasıl yansıdığını ve kendini nasıl ürettiğini göstermektedir. $\mathrm{Bu}$ durum mekânı kurgusal yapmakta, mekânın içinde yaşayan insanların bakış açısı ile değerlendirmelerine, algısal kapasite ve duyusal deneyimleriyle tanımlamalarına olanak vermektedir (Taşcı, 2014, s. 4-10).

Mekân yaratma "yer olabilme" açısından kamusal mekânın sürdürülebilirliği ve canlılığı, kamu yararı sağlayan kentsel çevrenin yaşamak, çalışmak için sağlıklı, güvenli, çekicilik özelliği göstermesine bağlıdır. Bu sebeple eşik mekânları aslında bir sınır, anlık bir geçiş alanından çok daha fazla anlam taşımaktadır (Andersson, 2016, s.167-168). Günümüz mimarlık ortamında çevre özelliklerini, kent yapısını dikkate alan, aynı zamanda teknolojik imkânlardan yaralanarak oluşturulan "yer" leşmiş "eşik"ler, Yeldeğirmeni- Rasimpaşa Mahallesi üzerinden incelenmiştir.

\section{Materyal ve Metot}

Çalışma alanı olan Yeldeğirmeni, güneyinde Recaizade Sokağı, kuzey ve doğusunda Anadolu demiryolu hattı, batısında ise Rıhtım Caddesi arasında yer almaktadır. Kentsel sit alanı olan bu bölge Kadıköy Rasimpaşa Mahallesi'nde bulunmaktadır. Adını 1774-1789 yılları arasında burada bulunan ve un üreten dört değirmenden alan bölgede, 19. yüzyıla kadar Türk ve Rumlar, ardından Museviler ikamet etmiştir. Tanzimat'ın ilanıyla birlikte Osmanlı Devleti'nde yaşayan gayrimüslimler bölgede yaşamaya başlamışlardır. Dolayısıyla Tanzimat sonrası korunan kat sınırında esneklikler görülmekle beraber yapısal açıdan bitişik nizamda katevler (apartman) inşa edilmiştir. (Karbeyaz, 2010, s.14-15) (Şekil 2).

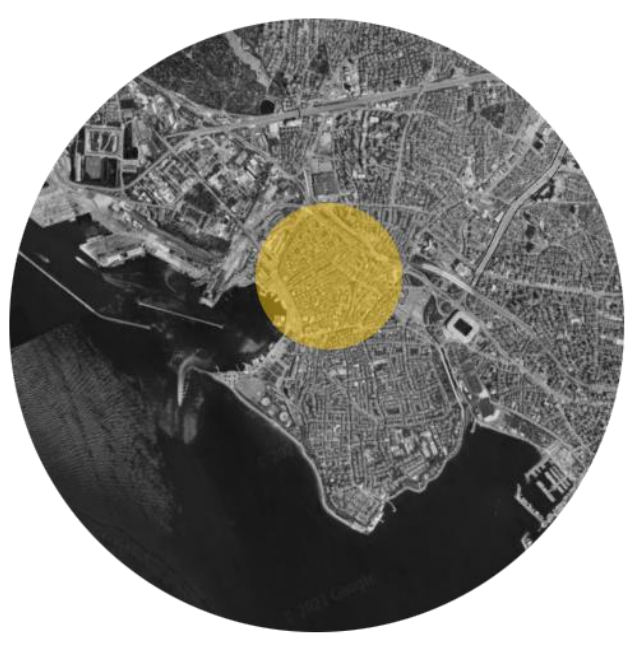

Şekil 2. Yeldeğirmeni Rasimpaşa Mahallesi’nin genel görünümü
$\mathrm{Bu}$ çalışma için Kadıköy Belediyesi’nden Yeldeğirmenini içeren 1/1000 Uygulama İmar Planı ve 1/15000 ölçekli Nazım İmar Planları temin edilmiştir. Mimari görselleştirme programlarından yararlanılarak mekânsal okumalar yapılmıştır. Konu üzerine ilgili tez ve araştırmalar incelenmiştir. Yeldeğirmeni-Rasimpaşa Mahallesi'nde saha çalışması yapılarak mekansal eşikler tespit edilerek, kentsel aidiyetin yeniden kurgulanması için potansiyel alanlar tespit edilmiştir.

\section{Araştırma Sonuçları ve Tartışma}

\subsection{Modern Kentte Yerel Arayüzler - Yeldeğirmeni- Rasimpaşa Mahallesi}

Geleneksel yapılaşmanın görüldüğü kent ortamının yenilenmesi, mekânı ve o mekâna yüklenen sosyal ve kültürel anlamları dönüştürmektedir. Kentsel çevreye bağlı gelişen sosyal ve duygusal anlamlar insanların zihnindeki fiziksel ve yapısal çevre imgesi kadar önemlidir. Mekâna anlam yükleyen bireyler, gruplar ve toplumlar boşluğu bir mekâna dönüştürmüşlerdir (Ujang, 2015, s. 709-710). Gelişen ekonomi sonrası konut talebini karşılamaya yönelik artan tek tip yapılaşma, kentlerde üst ölçek ile bütünleşmeyi zayıflatarak, mimarinin "yer" algısından bağımsız "kutu mimarileri" ş̧eklinde gelişmesine ortam hazırlamıştır. Özellikle 19. Yüzyılın ikinci yarısında artan işçi ve memur konut sorununa çözüm olarak gelişen demir-çelik ve beton malzemelerden üretilen blok düzen yapma biçimi modern ve çağdaş konut anlayışı olarak kentleri şekillendirmiş̧tir (Gökmen, 2011, s.13) Oysa kentlerde sosyal yaşamı biçimlendiren, yapıların formu ve yerleşim dokusu ile kurduğu ilişkidir. Bazen tek bir yapı formunun bile kent içerisinde nirengi özelliği göstererek, bir mekânsal organizasyon oluşturması mümkündür. Yeldeğirmeni anitsal ve sivil mimari örnekleri ile İstanbul'da çarşı kültürünün yaşatıldığı ve canlılığı korunan yerel arayüzlerdendir.

Yerleşim alanının tarihsel gelişimi incelendiğinde 1774-1789 yılları arası Yeldeğirmeni-Rasimpaşa Mahallesi'nde yapılaşmanın izleri görülmektedir. Johann Baptist von Reben (1764) ve Kauffer' in (1786) haritaları incelendiğinde Haydarpaşa kıyısında henüz hiçbir yerleşim yoktur. Kauffer'in (1786) haritasında bölgede küçük bir köy yerleşimi dikkati çeker (Şekil 3) (Arıker, 2019, s.59-60).

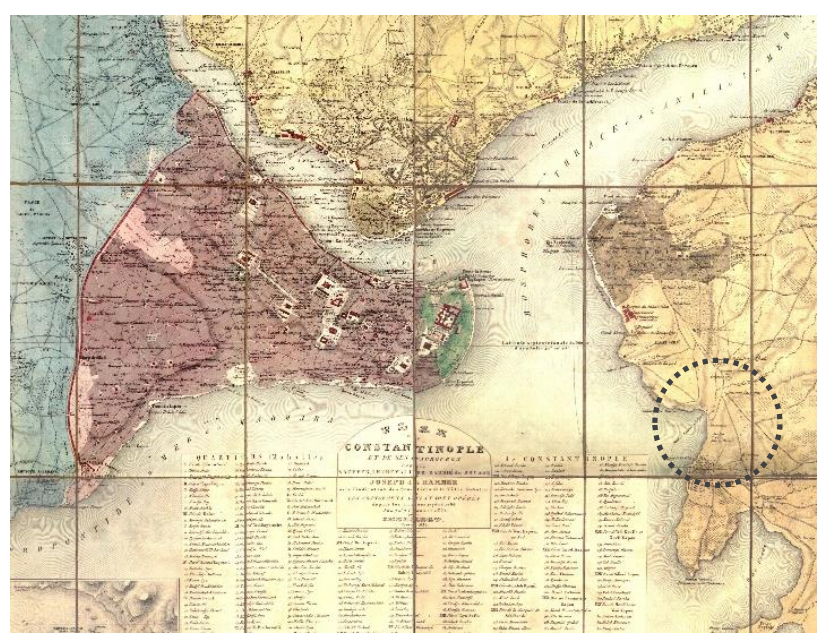

Şekil 3. Kauffer et Joseph de Hammer tarafindan 1786'da hazırlanan İstanbul haritası (SALT Araştırma, Kent Toplum ve Ekonomi Arşivi) 
19. yüzy1lda ise bölgede genişlemiş ve düzenli bir sokak dokusu görünümü hakimdir. 1860'lı yıllarda Kadıköy'de çıkan bir yangın sonrasında bölgede 1zgara düzende bir kent planlaması yapılmış ve köşe parsellerin pahlı hale getirilmesiyle mahalle içerisinde küçük meydanlar oluşmuştur (Arıker, 2019, s.64) (Şekil $4)$.

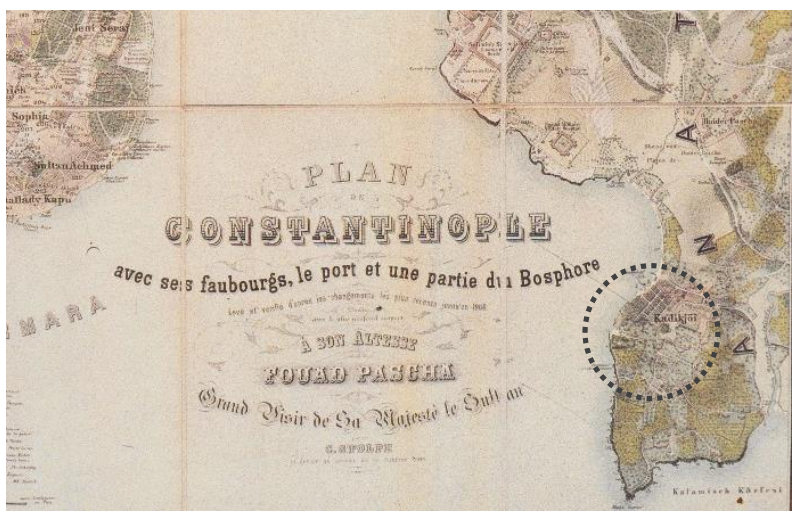

Şekil 4. 1863-1880 yılları arasında C. Stolpe taraşından çizilen İstanbul haritası (SALT Araştırma, Kent, Toplum ve Ekonomi Arşivi)

1906 yılında Charles Edward Goad tarafindan hazırlanan Haydarpaşa-Moda hattını gösteren rıhtım haritasına baktığımızda yap1 adalarının günümüzdeki, şeklini almaya başladığı görülmektedir (Arıker, 2019, s.66). Sokak örüntüsü ızgara plan tipine uygun olarak geliştirilmiştir (Şekil 5).

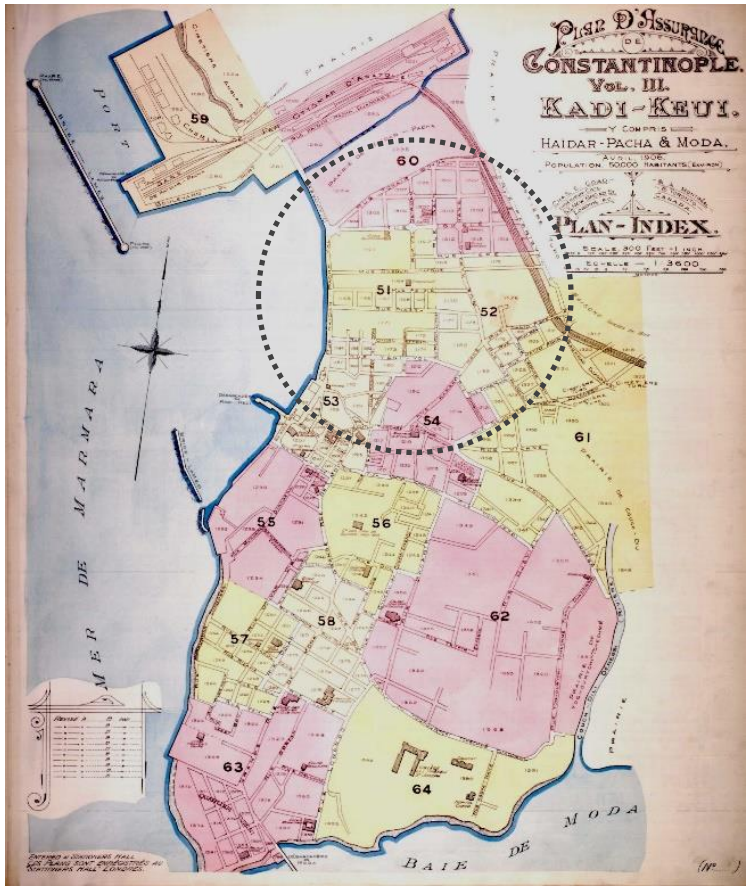

Şekil 5.1906 Kadıköy, Haydarpaşa-Moda bölgesini gösteren 1906 tarihli Goad haritası

1922-1945 y1lında hazırlanan Pervititch haritalarına bakıldığında birçok parselin imara açıldığı ve yapı adalarının bölündüğü görülmektedir. Bölgeye kagir ve betonarme yapılar hakimdir (Şekil 6) (Arıker, 2019, s.68).

Yeldeğirmeni-Rasimpaşa Mahallesi'nde günümüze ulaşan en erken tarihli yapılar 19. Yüzyıl sonu 20. Yüzyıl başına aittir. Rum ve Ermeni mimarlar tarafından inşa edilen bu yapıların bir bölümü, 1960 sonrasında (Karbeyaz, 2010, s.12) yıkılmış, ardından gelen tek tip yapılaşma ile kent dokusu yok olmuştur.
Bölgede yer yer korunarak günümüze ulaşabilen sivil mimari örnekleri ile kentsel bir arayüz oluşturan çıkma, cumba, niş, sütun, arkad, saçak, duvar, tente, örtü elemanı, avlu vb. mekânsal eşikler, zarar gören kent kimliğinin onarılması, devamlılığının sağlanması ve aidiyet duygusunun yeniden kazandırılması açısından önemli bir potansiyel barındırmaktadır.

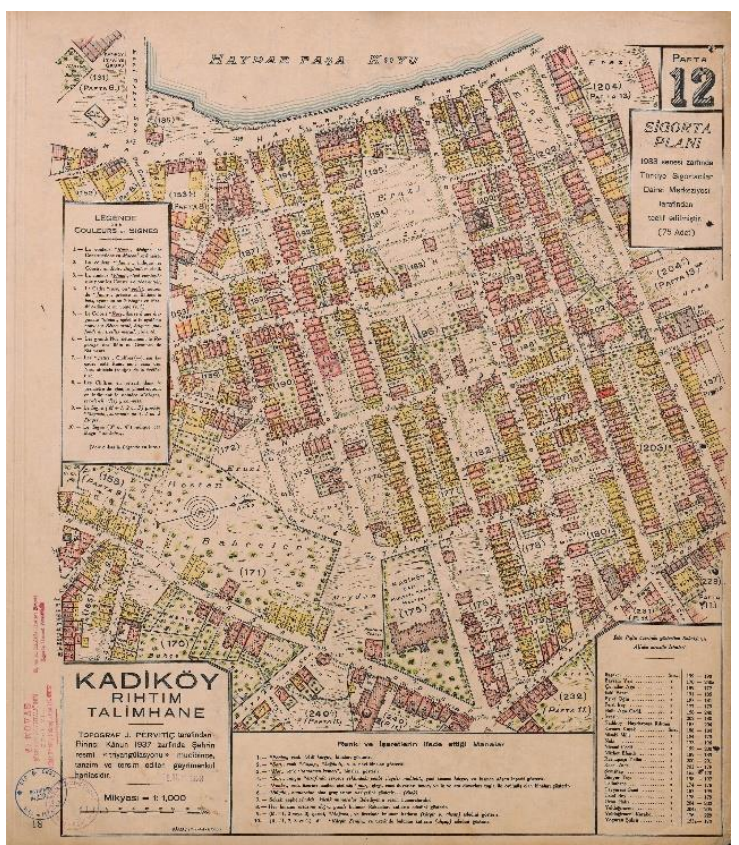

Şekil 6. Kadıköy rıhtımı gösteren 1938 tarihli Pervititch haritası (SALT Araştırma, Kent Toplum ve Ekonomi Arşivi

Yeldeğirmeni-Rasimpaşa Mahallesi'nde eşik oluşturan yapısal öğelerden en yoğun olanı çıkma-cumbalardır. Çıkma ve cumbalar kamusal ve özel mekân arasında bir arakesit oluşturarak yapının sokakla olan ilişkisini düzenlemektedir. İzleyicinin kentsel mekânı farklı açılardan deneyimlemesine olanak sağlamaktadır. Özel mekânı kentsel mekânın içine doğru genişleterek iç ve dış mekân arasındaki sınırı esnetmektedir.

Eşik oluşturan bir yapısal olan merdivenler, YeldeğirmeniRasimpaşa Mahallesi'nde yap1 girişlerinde karşımıza çıkmaktadır. Özel-kamusal, iç-dış mekân arasında bir geçiş alanı olan merdivenler hem yapıya hem de kente dâhil olarak bir ara mekân oluşturur. Burada birey hem kentin izleyicisi hem de öznesi konumundadır. Özellikle yapı girişlerinde yer alan merdivenlerin tarihten günümüze değin sosyal etkileşim alanları olarak kullanıldığı bilinmektedir. Basamak oturmalar, mekânda davet edici bir eylem olduğunda, insanların olayı görmelerini ve aynı zamanda içinde yer aldıkları hissi duymalarını da sağlamaktadır

Eşik olarak duvar; korunma, mahremiyet, güven, mülkiyet, sınır, savunma, inançları ifade etme gibi çeşitli amaçlarda kullanılmıştır (Alkaya, 2015, s.8). Yeldeğirmeni-Rasimpaşa Mahallesi'nde duvarlar, üzerine yapılan resimlerle düşey yönelimli görsel bir aktarım aracı olarak kullanılmıştır.

Arkadlar kentsel mekânda gölgelik alanlar ya da yağmur, kar vb. iklimsel koşullarda sı̆̆ınılan köşeler oluşturmanın dışında giriş mekânını vurgulamak gibi sembolik kullanımlara da izin vermektedir. Yeldeğirmeni-Rasimpaşa Mahallesi'nde arkadlar, kamu yapılarının girişinde kullanılmış olup, kent-kamu arasında bir ara mekân oluşturur (Şekil 7). 

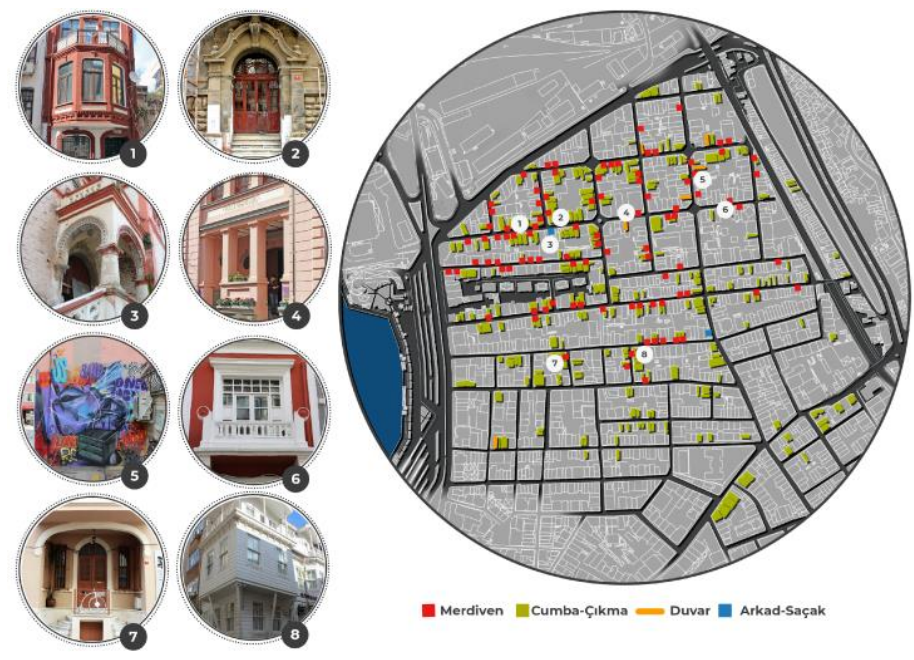

- Merdiven Eumba-çוkma - Duvar Arkad-Sąak

Şekil 7. Yeldeğirmeni-Rasimpaşa Mahallesi’nde yapısal eşiklerin analizi

Rasimpaşa mahallesinde kaldırım kafeler, caddeleri ticari aktivite mekânı haline dönüştürme açısından önemlidir. Restoran, cafe vb. işletmelerin içten-dışa genişlemesi kamusal yaşama enerji ve aktivite getirmektedir. $\mathrm{Bu}$ alanların özel işletmeler tarafından kiralanması kaldırımların çevre açısından açıklılık ve işlevsellik kazanmasına yardımcı olmaktadır (Boston Complete Street Guidelines, 2015). Yeldeğirmeni-Rasimpaşa Mahallesi'nde mekânsal eşik olarak kaldırım kafeler; iç-dış, kamusal-özel mekân arasında bir arakesit oluşturarak yapının kente dâhil olmasına olanak sağlamaktadır (Şekil 8).
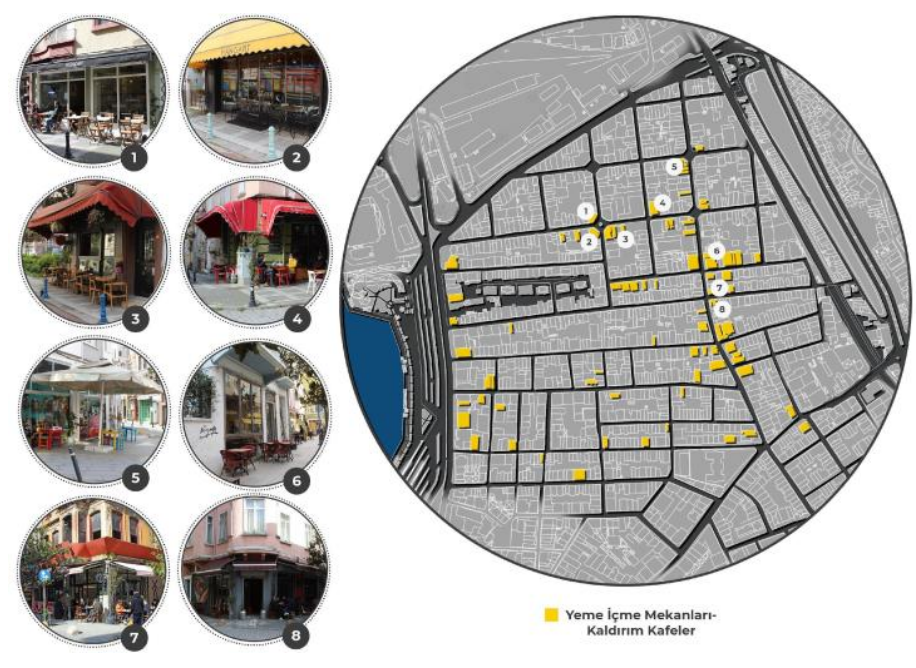

Şekil 8. Yeldeğirmeni-Rasimpaşa Mahallesi'nde yeme-içme alanları ve kaldırım kafelerin analizi

Yeldeğirmeni-Rasimpaşa Mahallesi'nde en az görülen eşik mekân avlular ve pasajlardır. Avlular bölgedeki sinagog, cami, kilise gibi dini yapıların bir parçası olduğu için gündelik hayata katılımı seçici ve sınırlıdır. Bölgedeki avluların aksine pasajlar ticari işlevlerinin de etkisiyle kent-yapısal arasındaki katı ilişkiyi yumuşatmış, pasajların kentin bir parçası haline gelmesini sağlamıştır (Şekil 9).
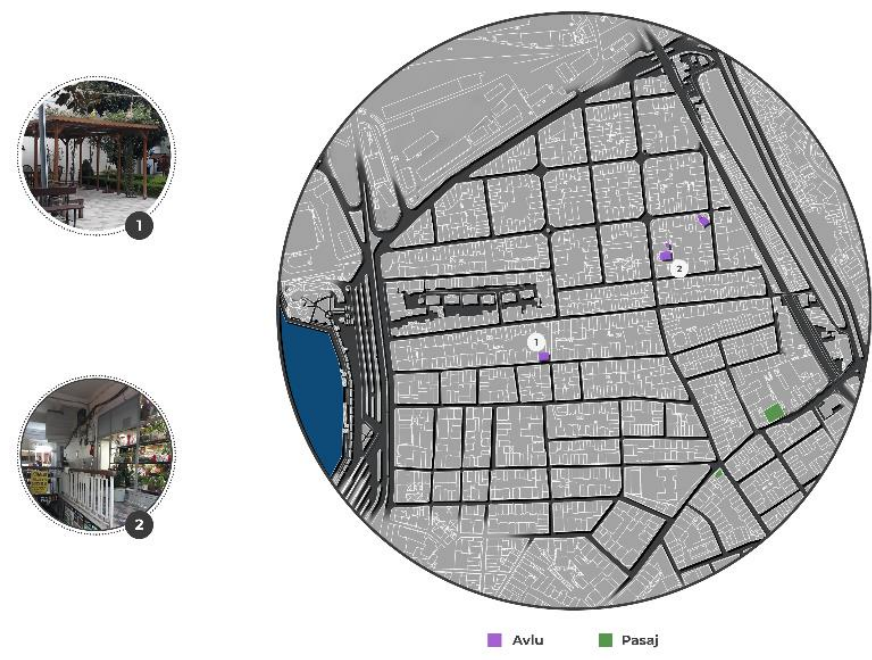

Şekil 9. Yeldeğirmeni-Rasimpaşa Mahallesi’nde avlu ve pasajların analizi

\section{Sonuç}

Ülkemizde özellikle kapitalist sistemlerin etkisi ile mevcut imar planlarının tek parsele dayalı niceliksel ölçütlerden yararlandığı bilinmektedir. Bu tek parsellerin eklemlenmesi ile bir bütün halinde kentsel çevreler üretilmektedir. Yapı alanının, yapı yüksekliğinin ve çekme mesafelerinin denetlenebildiği bu sistemsel döngü yapıyı çevresi ile birlikte ele almada özellikle insan-yapılı çevrenin niteliğini sorgulamada yetersiz kalmaktadır. Çoğunlukla birbirine benzer yapı gruplarının bir araya gelmesi ile tek tip ve birbirinin benzeri mekânlar oluşmaktadır. Bunun sonucunda yerleşimlerde özgün bir karakter altyapısı sağlanamamakta, kentler birer yapı yığınına dönüşmektedir. Kentsel çevre, kapsamına aldığı mimari yapılanmadan bağımsız düşünülmemelidir. Kentsel ve mimari mekân karşılıklı bir etkileşim ve dönüşüm içerisindedir. Bu noktada eşik alanları hem yapıdan hem de kamusal alandan ayrı düşünülen "ayrık" ve "kayıp" alanlar olarak soyutlanmaktadır.

Yeldeğirmeni-Rasimpaşa Mahallesi’nde mekânsal bir arayüz olarak eşikler, kent kimliğini yeniden kurgulamak için potansiyel barındırmaktadır. $\mathrm{Bu}$ potansiyel, Yeldeğirmeni Rasimpaşa Mahallesi'nde "artık mekân" haline gelen eşiklerin tasarım nesnesi olarak değerlendirilmesiyle ve kamu-özel, iç-dış, kentmimari yapı arasındaki ilişkinin düzenlenmesiyle yer algısına imkân veren bir mekânsal dizim olarak var olmaktadır.

Eşik mekânlar "müşterekliğin" alanlarıdır. Ne yapı ne de kent planlaması ve tasarımından ayrı düşünülmemelidir. Eşikler etkin cephe tasarımı ve erişilebilir nitelikte sağladıkları kamusal alan tasarımları ile kentsel mekânın süreklilik ve kapalılığını destekleyerek, kent kimliğinin özellikle de "yer" algısının oluşmasına katkı sağlamaktadır. Kentin çeperlerini oluşturan cephelerin (dikey ve yatay bileşenlerin) sokak ile ilişkiyi etkin bir şekilde yansıtması beklenir. Bu noktada yerel yönetimler, meslek odaları, mimar ve kentsel tasarım uzmanlarından beklenen kentin kendi yerelliklerini koruyacak mimari detayları tasarım ve projelerine yansitmalarıdır.

Ulusların geçmişten bugüne değin kendi kimlik ve kültürlerini koruma çabası da günümüz mimarlarını sürdürülebilirlik kavramı içerisinde geleneksel mimariye yönlendirmektedir. $\mathrm{Bu}$ noktada geleneksel ve yerel kimliği, sosyo-kültürel bir değer olarak algılayan alternatif mimari mekân 
çözümleri kapsamında “eşik” alanların değerlendirilmesi oldukça önemlidir.

\section{Teșekkür}

$\mathrm{Bu}$ çalışmanın ortaya çıkması için desteğini esirgemeyen Kadıköy Belediyesi'nden Batuhan Akkaya'ya teşekkürlerimizi sunariz.

\section{Kaynakça}

Alkaya,T. (2015). Sınır ve eşik olarak duvar. (Yayımlanmamış Yüksek Lisans Tezi). İstanbul Teknik Üniversitesi, Fen Bilimleri Enstitüsü, Mimarlık Anabilim Dalı, İstanbul.

Andersson, C., (2016). Public Space and the new urban agenda. The Journal of Public Space. 1(1), 5-10.

Arefi, M. (1999). Non-place and placelessness as narratives of loss: Rethinking the notion of place. Journal of Urban Design, 4(2), 179-193.

Arıker, E. (2019). Âtıl yarı özel alanları sahiplenmek: Yeldeğirmeni Mahallesi'nde arka bahçeler. (Yayımlanmamış Yüksek Lisans Tezi). İstanbul Bilgi Üniversitesi, Lisansüstü Programlar Enstitüsü, İstanbul.

Aytıs, S., Polatkan, I., (2010). Gelenekten geleceğe mimarlık. VI. Uluslararası Sinan Sempozyumu, Edirne.

Ayyıldız, M. A. (2000). Insan-çevre diyalektiğinin duyusalzihinsel-duygusal süreçleri: Çevresel algl-bilişim-anlam (Yayımlanmamış Yüksek Lisans Tezi). İstanbul Teknik Üniversitesi, Fen Bilimleri Enstitüsü, İstanbul.

Berman, M. (1994). Katı olan her şey buharlaşıyor. (Çev. Ü. Altuğ ve B. Peker) İstanbul: İletişim Yayınları.

Bertlin, J. (2014). Social sustainability from the perspective of three concepts: human scale, the city at eye-level, and public life. KTH Royal Institute of Technology, School of Architecture and the Built Environment (ABE), Urban Planning and Environment, Urban and Regional Studies, Stockholm.

Cassidy, T. (1997). Environmental design in environmental psychology, behaviour and experience in context. London: Psychology Press.

Dizman, O.K., (2015). Geçişlilik kavramının mekâna anlamsal ve simgesel yansımaları. (Yayımlanmamış Yüksek Lisans Tezi). Yakın Doğu Üniversitesi, Fen Bilimleri Enstitüsü, Mimarlık Anabilim Dalı, Lefkoşa.

Geis, K. J., \& Ross, C. E. (1998). A new look at urban alienation: The effect of neighborhood disorder on perceived powerlessness. Social Psychology Quarterly. 61(3), 232-246.

Gezer, H. (2014). Mimariyi yaşamak. Istanbul Ticaret Üniversitesi Fen Bilimleri Dergisi, 13(26), 227-258.

Gibson, J.J. (1979/86). The ecological approach to visual perception, Houghton Mifflin, Boston.

Gökçen, A. (2019). Eşik: Olgular ve imgeler bağlamında bir mekân analizi. Íçtimaiyat Sosyal Bilimler Dergisi. 3(2), 129137.

Gökmen, G. P. (2011). Türkiye'de Apartmanlaşma Süreci ve Konut Kültürü. Güney Mimarlık, 5, 12-17.

Hidalgo, M. C., \& Hernandez, B. (2001). Place attachment: Conceptual and empirical questions. Journal of environmental psychology, 21(3), 273-281.

Ittelson, W. H. (1960). Visual space perception. New York, N.Y: Springer.
Jacobs, J. (2009). Büyük Amerikan şehirlerinin ölümü ve yaşamı. (Çev. B. Doğan). İstanbul: Metis Yayınları.

Karbeyaz, C. (2010). Kadıköy Yeldeğirmeni'nde Notre Dame du Rosaire Şapeli restorasyon projesi. (Yayımlanmamış Yüksek Lisans Tezi). İstanbul Teknik Üniversitesi, Fen Bilimleri Enstitüsü, Mimarlık Anabilim Dalı, İstanbul.

Lynch, K. (1960). The image of the city. London: MIT press.

Montgomery, J. (1998). Making a City: Urbanity, Vitality and Urban Design. Journal of Urban Design, 3, 93-116.

Öztürk, S., ve Osmanoğulları, F. (2016). Blue in the Face filmi ve modernizm: Kentlilik ve aidiyet üzerinden bir değerlendirme. Mediterranean Journal of Humanities. 4(1), 261-274.

Plan de Constantinople et de ses faubourgs d'après Kauffer et Joseph de Hammer avec l'indication des quartiers de la ville (Mahalle) et les changements qui s'y sont opérés depuis les années 1776 et 1786 jusqu' à l'année 1831. Paris 1836 , Kauffer et Joseph de Hammer, APLHM01 SALT Araştırma, Kent Toplum ve Ekonomi Arşivi, https://archives.saltresearch.org/handle/123456789/112045

Plan de Constantinople avec ses faubourgs, le port et une partie du Bosphore. Echelle: 1:13000- İstanbul ve civarını, liman ve Boğaz'ın bir bölümünü gösteren harita. Ölçek 1:13000, 18631880, FFT811013, SALT Araştırma, Kent, Toplum ve Ekonomi Arşivi, https://archives.saltresearch.org/handle/123456789/25359

Plan d'assurance de Constantinople. Vol. III- Kadikeui. Index, Charles Edward Goad, 1906, APLGDKADINDX, SALT Araştırma, Kent, Toplum ve Ekonomi Arşivi, https://archives.saltresearch.org/handle/123456789/126275

Sigorta Planı. Kadıköy. Rıhtım- Talimhane. Pafta 12. Jacques Pervititch, 1938, APLPEKADI12, SALT Araştırma, Kent, Toplum ve Ekonomi Arşivi, https://archives.saltresearch.org/handle/123456789/109107

Sorguç, A., \& Arslan Selçuk, S. (2016). Sınırlanmıştan sınıra sınırdan arayüze sayısaldan fiziksele. Mimarlık dergisi. 52(388), 57-58.

Şentürk, A. (2018). Aidiyet, kent kimliği ve kentsel koruma etkileşimi bağlamında kullanıc sürekliliğinin irdelenmesi: Kadıköy Moda örneği. (Yayımlanmamış Doktora Tezi). İstanbul Teknik Üniversitesi, Fen Bilimleri Enstitüsü, İstanbul.

Şevik, E., Çalışkan, O. (2018). Heterotopyanın Alansallığı: Heterotopolojinin Temel Mekânsal Koşulu Olarak Kentsel Eşikler. "Değişen Kent”, Mekân ve Biçim: Türkiye Kentsel Morfoloji Araştırma Ağı II. Kentsel Morfoloji Sempozyumu. https://kentselmorfolojisempozyumu2018.files.wordpress.co $\mathrm{m} / 2019 / 04 / \mathrm{m}-46 . p d f$

Taşcı, H., (2014). Bir hayat tarzı olarak şehir, mekân, meydan. İstanbul: Kaknüs Yayınları.

Tuncer, M.,(2012). Makro planlamada eşik analizi: SWOT, Stratejiler, Alt Projeler. http://tuncermehmet.blogspot.com/2012/10/makroplanlamada-esik-analizi-swot.html.

Ujang, N. (2012). Place attachment and continuity of urban place identity. Procedia-Social and Behavioral Sciences, 49, 156167.

Ujang, N. ve Zakariya, K. (2015). The notion of place, place meaning and identity in urban regeneration. Procedia-social and behavioral sciences, 170, 709-717. 